The article examines the essence of legal monitoring and the effectiveness of law, the issue of their relationship. The author emphasizes that the legal monitoring it is necessary to understand the method by which the quality and efficiency of the mechanism of legal regulation is checked, the law-making errors of the corresponding normative-legal material are revealed, the prediction and diagnosis of problems of the legal system and timely reaction are realized. At the same time, the effectiveness of law is determined by the researcher as a correlation between the actual and desired results of the legal norms, the level of achievement of the purpose of their adoption, which depends on the interaction of law-making activity actors, the quality of normative and legal acts, the effectiveness of the implementation and securing of the law, the level of legal consciousness, and the legal culture of society.

The author's outline is that legal monitoring includes the effectiveness of law, while the legal, socially oriented state must act at all stages of rulemaking and enforcement.

Key words: monitoring, legal monitoring, law effectiveness, evaluation, analysis.

DOI: 10.33.66.3/2524-017X-2019-10-247-252

УДК 340.1

Сергій Олександрович Сунєсін, науковий співробітник відділу теорії держави і права Інституту держави і права ім. В. М. Кореиького НАН Украӥни, кандидат юридичних наук

\title{
ПРАВОВА СИСТЕМА: ПРОБЛЕМИ ЕФЕКТИВНОСТІ В КОНТЕКСТІ СУЧАСНИХ ТЕНДЕНЦІЙ ПРАВОВОГО РОЗВИТКУ
}

Постановка проблеми. Питання формування та розвитку правових систем сучасності в складних та суперечливих умовах сьогодення $є$ одним із найбільш досліджуваних у вітчизняній та зарубіжній юридичній науці, зокрема, в межах загальнотеоретичного правознавства. Вказаний факт слід визнати цілком закономірним, оскільки такий величезний науковий інтерес до цієї проблематики обумовлюється насамперед об'єктивними чинниками, які вимагають здійснення належного доктринального осмислення (переосмислення) тих чи інших особливостей формування, функціонування і розвитку правових систем з урахуванням тих вимог, викликів та загроз, які висуваються багатоманітною соціальною дійсністю.

У зазначеному контексті мова йде, зокрема, про процеси глобалізації, технократизації та інформатизації, які призводять до неоднозначних та нерідко вкрай суперечливих соціальних наслідків; ускладнення характеру взаємодії в системі координат «особа - громадянське суспільство - держава»; посилення атомізації суспільства, у тому числі у розвинених демократичних державах; поширення соціальної аномії тощо. В таких складних нинішніх реаліях все більш очевидним стає, що правова система недостатньо ефективно виконує свої основні функції, зокрема, регулятивну та охоронну, незважаючи на всі реформаторські заходи, яких вона зазнає, та сподівання, які на неї покладаються 3 боку суспільства та громадян. 3 огляду на це, особливу актуальність та значущість набуває дослідження питань, пов'язаних з визначенням та правильним розумінням тих причин і умов, які обумовлюють низьку ефективність функціонування та розвитку правових систем сучасності.

Аналіз останніх досліджень та публікацій. Якщо звернутися до сучасного наукового доробку вітчизняних та зарубіжних вчених, то можна пересвідчитися, що різноманітні питання формування, функціонування та розвитку як правових систем, так і їх окремих структурних елементів, вже неодноразово були предметом доктринального осмислення, зокрема, таких вчених, як Г. Дж. Берман, С. Бобровник, Р.Давид, Д. Ллойд, О. Львова, Г. Мальцев, В. Нерсесянц, Н. Оніщенко, Н. Пархоменко, О. Петришин, А. Поляков, О. Тихомиров, С. Шевчук, Ю. Шемшученко тощо. Втім, реалії сьогодення переконливо доводять необхідність переосмислення насамперед тих причин і умов, які гальмують ефективний розвиток правової системи та її складових, унеможливлюючи тим самим її якісний нормативно-організуючий вплив на суспільні відносини. 
Сунсзін С. О. Правова система: проблеми ефективності в контексті сучасних тенденцій...

Мета статті. Метою цієї статті є загальнотеоретичне осмислення сучасних тенденцій правового розвитку, зміст яких впливає на ефективність функціонування правової системи.

Основні результати дослідження. Переходячи до безпосереднього висвітлення основного змісту даної статті, насамперед зазначимо, що не можна вести мову про універсальність та однорідність тенденцій правового розвитку сучасних демократичних держав, оскільки різними $є$ самі суспільства, які утворюють відповідні держави, соціокультурні засади їх історичного становлення та розвитку, ментальні та світоглядні характеристики, морально-релігійні системи тощо, які у своїй сукупності та взаємозв'язку справляють певний вплив, зокрема, на специфіку національного демократичного та правового розвитку. Водночас, з огляду на глобалізаційний вимір сучасного світопорядку, можна вести мову хоча б про деякі або окремі загальні тенденції сучасного демократичного правового розвитку, які в тій чи іншій мірі $є$ характерними для всіх суспільств, що закріплюють демократичні стандарти суспільного життя, а саме:

1. Посилення правового регулювання як приватних, так і публічних відносин, що виражається, зокрема, у зростанні нормативно-правового масиву або кількості нормативно-правових актів різної юридичної сили, які регламентують відповідні суспільні відносини. У зазначеному контексті мова йде не лише про зростання кількісних показників нормативно-правових актів, а й про їх якісне насичення, одним із проявів якого $є$ все більша демаркація лінії розмежування між приватним та публічним правом, що, з одного боку, свідчить про значну динаміку розвитку відповідних суспільних відносин, які вимагають свого належного правового оформлення, а з іншого - призводить до посилення невизначеності конкретних результатів правового регулювання.

Так, слід підтримати думку науковців, які вважають, що межа між публічним та приватним правом $€$ нечіткою і в сучасних умовах все більше «розмивається»; при цьому цивільному праву, яка $€$ «класичною» галуззю приватного права, все більше протиставляється не лише підприємницьке право, а й спадкове, сімейне, земельне право та право інтелектуальної власності, в яких все більше додаються публічно-правові елементи (наприклад, значна кількість імперативних норм, встановлення спеціальної правосуб'єктності певних осіб тощо). Це, у свою чергу, починає призводити до суттєвої перебудови та переосмислення всього предмета цивільного права $[1$, с. $108 ; 2$, с. $264 ; 3$, c. 7-9; 4, с. 50-55; 5, с. 26]. Справді, після ухвалення Господарського, Сімейного, Бюджетного, Податкового та Земельного кодексів України норми Цивільного кодексу в певній мірі втратили сферу свого застосування. Зрозуміло, що в цих умовах:

а) по-перше, суттєво актуалізується необхідність забезпечення узгодженості між відповідними правовими нормами, оскільки спеціальні норми права, хоча й можуть мати характер виправданих специфікою певних правовідносин винятків із загального правила, проте не повинні ігнорувати його зміст або фактично відміняти його з огляду на те, що вони мають перевагу у застосуванні до особливих відносин, яким вони, власне, і присвячені;

б) по-друге, усунення колізійності або неузгодженості правових норм передбачає не лише здійснення відповідних юридико-технічних операцій, спрямованих на їх досконале формулювання та виклад, а, що найважливіше, на забезпечення їх належного подальшого розуміння і сприйняття всіма адресатами - суб'єктами права, які їх безпосередньо реалізують. Адже право реалізується відповідним чином лише в актах поведінки та діяльності суб'єктів правовідносин, а не як визначена поведінкова зразкова модель абстрактного характеру, закріплена в нормі. Право взагалі втрачає свій сенс та регулятивно-охоронний потенціал, якщо воно не реалізується або реалізується в діях та поведінці суб'єктів права всупереч своєму загальному соціальному призначенню - формування та утвердження стабільного порядку в суспільно-державному житті на всіх рівнях;

в) по-третє, посилення конкуренції правових норм у сфері приватного та публічного права обумовлює все більшу невизначеність правореалізаційної діяльності взагалі та правозастосовної зокрема, оскільки відповідні суб'єкти для вирішення певної практичної, юридично та соціально значущої ситуації вимушені обирати на власний розсуд один варіант з двох чи більше правових норм, які формально можуть не суперечити одна одній. Як наслідок, суттєво розширюються межі правореалізаційного розсуду, вплив на який не обмежується, власне, правовою матерією. Більше того, значні обсяги законодавства та внесення постійних змін і доповнень до нього з метою його удосконалення нерідко призводить до такого закономірного в цих умовах наслідку, як прийняття протилежних рішень у аналогічних справах або ситуаціях. Це, у свою чергу, порушує принцип єдності правореалізаційної практики та, врешті-решт, негативно позначається на захисті прав, свобод і законних інтересів фізичних та юридичних осіб. 
У зазначеному контексті слід погодитися з думкою, що наслідками, зокрема, «великої кількості колізій у податковому законодавстві є значне погіршення ефективності оподаткування та податкової політики України, зведення нанівець стимулюючої ролі податків, зменшення надходжень до Державного бюджету, підвищення рівня корупції» [6, с. 116].

2. Наступною загальною тенденцією сучасного правового розвитку є універсалізація та уніфікація права, які все більше набувають багатоаспектного, внутрішньо суперечливого характеру і найбільш виражено проявляються в економічній сфері суспільного життя, що, у свою чергу, є основою здійснення відповідних процесів універсалізації та уніфікації. У науковій літературі з цього приводу, зокрема, зазначається, що «формування і розвиток права - незважаючи на всі особливості національних систем права - являють собою історію його все більшої універсалізації та уніфікації, історію руху до все більш глобального права, причому всі ці історично прогресуючі властивості і характеристики права, що розвивається, знаходять своє вираження, закріплення та здійснення як в окремих національно-державних системах права, так і в міжнародному праві» [7, с. 40].

Погоджуючись загалом 3 тим фактом, що основу соціального розвитку майже завжди складала ідея об’єднання, синтезу кращих культурних досягнень та надбань людства, що знаходить своє безпосереднє вираження, зокрема, у праві як особливому феномені культури, все ж це зовсім не означає, що універсалізація, уніфікація права неминуче призводять до прогресивного розвитку суспільства в цілому та правового прогресу зокрема. При цьому потрібно бути особливо обережними в оцінках розвитку сучасного етапу універсалізації та уніфікації права, який в нинішніх глобалізаційних умовах, як справедливо наголошують окремі сучасні дослідники, має «не еволюційний, а вибуховий, революційний характер» [8, с. 119].

Справа в тому, що універсалізація та уніфікація права як два взаємопов'язані та взаємно обумовлені процеси, що спрямовані на формування однорідності або гомогенності права, його норм, інститутів та цінностей в планетарному масштабі, об'єктивно вимагають своєї кореляції та узгодження з відповідними складовими різноманітного цивілізаційно-культурного простору, які деталізуються в межах національних та локальних суспільств і спільнот (народів, націй, етнічних груп тощо). При цьому уніфікація та універсалізація права, незалежно від того, в якій конкретно формі вони втілюються (наприклад, адаптація, гармонізація законодавства), передбачають визначення певного ціннісного стандарту, своєрідного правового еталона або взірця, корисність та прогресивність якого не повинна заперечуватися чи ставитися під сумнів, оскільки його ідейно-нормативний зміст слугує «відправним пунктом»у здійсненні даних процесів, підлаштовуючи під себе зміст будь-яких інших нормативних конструктів.

3 цього випливає, зокрема, той факт, що закріплення на нормативно-правовому рівні відповідних цінностей, стандартів та взагалі будь-яких правил поведінки, навіть якщо вони мають статус так званого міжнародного визнання, передбачає їх співвіднесення насамперед з іншими соціальними регуляторами, які завжди в тій чи іншій мірі мають місце в будь-якому суспільстві.

У зазначеному контексті мова йде насамперед про морально-релігійну систему нормативних координат, положення якої пред’являють відповідні вимоги не лише до дій, вчинків, поведінки та діяльності особистості, а й до їі смаків, внутрішніх переконань, прагнень, уподобань, емоцій, почуттів, думок тощо. На відміну від права, формування та розвиток якого історично майже завжди пов'язувалося $з$ державою, морально-релігійна система координат виникає разом з першими людськими спільнотами та суспільствами, оскільки саме 3 цього моменту починають оформлятися змістовні характеристики центральних понять моралі та релігії, якими є добро і зло. При цьому слід звернути увагу на те, що морально-релігійна система координат та історично сформований на іiі базі відповідний світогляд не можна обмежувати лише дескриптивним контекстом, який описує морально-релігійні цінності та норми з огляду на їх суспільний та особистісний статус, відповідаючи таким чином на питання, що вважається хорошим або поганим в межах певної соціальної структури. Адже в моралі, а особливо в релігії, чимало цінностей та норм усвідомлюються суб'єктами як такі, що визначають ті чи інші аспекти добра і зла поза контекстом певних темпорально-просторових вимірів, тобто незалежно від цінностей та норм різних культур і суспільств.

Більше того, не можна не звернути увагу на характер сучасного етапу розвитку відповідних процесів глобалізації, які виражаються, зокрема, в універсалізації та уніфікації демократичного правового розвитку. На сьогодні вже стає все більш очевидним, що в ньому питому вагу складають суб' єктивні чинники, які проявляють себе, серед іншого, в тому, що найбільш економічно, промис- 
Сунєгін С. О. Правова система: проблеми ефективності в контексті сучасних тенденцій...

лово та технологічно потужні держави прагнуть поширити на всі інші регіони світу свої «правила гри», чого можливо досягти насамперед шляхом використання відповідних правових механізмів. При цьому саме з цим, на думку автора, і пов'язується «революційний» або «вибуховий» характер сучасного етапу універсалізації права, про який зазначають сучасні дослідники.

Безумовно, уніфікація правових стандартів соціально-економічного, політичного та культурного життя в державах, які розвивалися в іншій соціокультурній системі координат, не може не позначитися на цілісності та узгодженості всієї сукупності нормативних регуляторів, які функціонують в конкретному суспільстві з урахуванням історичної традиції його розвитку. Слід погодитися 3 думкою, що процес адаптації законодавства України до законодавства Європейського Союзу та норм міжнародного права уповільнюється об'єктивною різницею історичного та соціокультурного розвитку відповідних правових систем [9, с. 18].

Саме тому питання універсалізації, уніфікації, гармонізації права тощо, повинні завжди співвідноситися з особливостями функціонування та розвитку всіх нормативних складових культури певного суспільства, а також специфікою світосприйняття, ментальності, ціннісних орієнтації, національних традицій, звичок, стереотипів поведінки тощо. Якщо ж таким співвіднесенням знехтувати, що може мати місце лише внаслідок домінування суб'єктивного чинника, наслідки такої універсалізації та уніфікації права матимуть здебільшого негативний характер.

3. Ще однією помітною тенденцією сучасного правового розвитку, яка тісно пов'язана 3 попередніми двома та по суті обумовлюється ними, $є$ посилення та одночасно ускладнення взаємозв'язку і взаємодії міжнародного, регіонального та національного права, що проявляється, зокрема, у все більшій імплементації у національних законодавствах загальновизнаних норм та принципів міжнародного права та закріплення, як правило, на конституційному рівні його примату над внутрішньодержавним правом.

Взагалі, питання співвідношення міжнародного та національного (внутрішньодержавного) права $\epsilon$ надзвичайно багатогранним вже 3 огляду на той факт, що саме поняття «право», яке утворює ці два поняття, містить в собі чимало «зрізів» або «площин» його системного осмислення. Адже про право як про соціальний феномен можна говорити як 3 точки зору втілення в його змісті фундаментальних принципів людського буття (справедливість, рівність, гуманізм, свобода), так і з точки зору джерел або форм відображення його ціннісно-нормативного змісту, а також у контексті суспільних відносин та його внутрішньої будови тощо.

Втім, все більш складний та неоднозначний характер взаємозв'язку та взаємодії міжнародного і національного права в сучасних умовах обумовлюється не лише неоднозначністю ціннісно-смислового контексту феномену «право». Останнє пов'язано, зокрема, з тим, що норми внутрішньодержавного та міжнародного права формуються і приймаються у різний спосіб та різними суб'єктами, у зв'язку з чим в їх зміст вкладаються неоднакові смислові параметри, які в межах окремих темпорально-просторових координат не можуть однаково тлумачитися, інтерпретуватися та реалізовуватися тими суб'єктами, на яких вони поширюють свою дію. Такі норми, незважаючи на їх категоріально-термінологічну та юридико-технічну подібність, а в окремих випадках навіть і тотожність, формувалися та розвивалися в різних соціокультурних системах для забезпечення виконання неоднорідних функцій і завдань. У зв'язку з цим, навіть надання таким нормам у встановленому порядку статусу загальнообов'язкових на території відповідних держав не може не позначитися щонайменше на національній специфіці їх сприйняття та реалізації, не кажучи вже про проблеми сучасного політичного «підтексту» міжнародних та міждержавних відносин, що обумовлюють ситуацію суб'єктивної «вибірковості» у виконанні міжнародних зобов'язань чи навіть їх повного нехтування.

Сьогодні стає все більш очевидним, що навіть якщо розглядати міжнародне та внутрішньодержавне право як такі системи, які мають єдину соціальну природу в центрі - людину, ії права і свободи, честь та гідність, недоторканність і безпеку [10, с. 32] - це зовсім не гарантуватиме ефективності імплементації відповідних міжнародно-правових стандартів у національне право. Даний факт можна пояснити тим, що права людини, незалежно від їх конкретного різновиду, $є$ багатоаспектним цілісним явищем, якому властиве різне аксіологічне «забарвлення» та соціокультурний релятивізм. Щодо універсальності прав людини, на якій найчастіше акцентується увага у сучасному дискурсі, то її потрібно розуміти як всезагальну формулу, завдяки якій досягнута згода міжнародного співтовариства щодо розуміння значущості кожної особистості, необхідності ії під- 
тримки та збереження за допомогою визначених національних механізмів. Універсальність прав людини базується на міжцивілізаційному поєднанні їх світоглядних, моральних, соціокультурних, національних ознак тощо, на досягненні їх єдності у багатоманітності, а не їх змістовної однаковості. Саме тому помилково розуміти універсальність прав людини як пристосування їх конкретного змісту під визначений стандарт, що претендує на статус всезагального.

У зв’язку з цим, примат міжнародного права над внутрішньодержавним, навіть у контексті так званих міжнародно-правових стандартів та принципів прав і свобод людини, вимагає свого адекватного розуміння та підходу до національного впровадження, завдяки якому можна досягти суттєвого зменшення «напруги» у взаємовідносинах між державами, а також покращити ефективність взаємозв’ язку та взаємодії міжнародних та національних правових норм.

Крім цього, не можна нехтувати також і тим фактом, що безумовний або безапеляційний примат норм міжнародного права над внутрішньодержавним правом, по суті, нівелює значення державного суверенітету як однієї з обов'язкових ознак будь-якої держави. Адже подібна постановка питання без жодних застережень фактично обмежує незалежність держави у зовнішніх відносинах, а також верховенство державної влади над суспільством та громадянами. Іншими словами, в цих умовах держава фактично не може повноцінно забезпечувати свої національні інтереси, зокрема, територіальну, соціальну цілісність, життєво важливі економічні потреби, культурно-духовну безпеку тощо, які завжди були і залишатимуться справжнім основним мотивом діяльності держави на міжнародній арені [11, с. 164-169]. Саме тому закріплення цього принципу у його сучасній ліберально-демократичній формулі насправді спрямовується не на зміцнення законності та правопорядку в межах визначених національних кордонів, а на забезпечення інтересів лише найрозвиненіших держав світу у соціально-економічному, політичному, науково-технічному та військовому відношеннях, які у зв'язку із цим є головними суб'єктами міжнародного права, спрямовуючи його розвиток, як правило, на подальше зміцнення свого світового впливу.

4. Наступною і останньою тенденцією сучасного правового розвитку, на якій би хотілося б зосередити певну увагу, є тенденція політизації права як на міжнародному, так і національному рівнях. Вказана тенденція проявляється насамперед у тому, що право використовується як інструмент досягнення певних політичних цілей, зокрема, забезпечення політичного владарювання, формування необхідної для визначених політичних кіл громадської думки тощо. Як справедливо зазначає Н. Оніщенко, «законодавство оцінюється сучасним суспільством як: а) знаряддя для силового забезпечення проведення певної політики; б) засіб здійснення певних управлінських завдань; в) веління держави» [12, с. 36].

У зазначеному контексті слід відзначити, що політизація права, так само як і політизація інших важливих сфер суспільного життя, має об'єктивні передумови. Стосовно політизації правової сфери ці передумови випливають насамперед 3 тісного взаємозв'язку права і політики як явищ соціальної дійсності, а також з необхідності забезпечення владно-організуючого впливу на суспільне життя. Політизація ж інших важливих сфер та питань суспільного життя (наприклад, економіки, освіти, культури, моралі тощо), окрім зазначених об’єктивних передумов, пов’язується також 3 необхідністю забезпечення належного реагування насамперед з боку держави та і1і інституцій на соціальні виклики і загрози, які нерідко супроводжують розвиток відповідної сфери.

3 огляду на зазначене, політизація як процес посиленого впливу політики на інші сфери суспільного життя шляхом надання політичного імпульсу, контексту або статусу тим явищам і проблемам, зміст яких є автономним та перебуває поза політикою, може виконувати позитивну роль у забезпеченні прогресивних соціальних перетворень, якщо вона засновується на об'єктивних передумовах та здійснюється виважено, професійно, добросовісно тощо. Зокрема, як свідчить історичний та сучасний досвід, кризи у відповідній сфері суспільного життя, наприклад, в економіці, об'єктивно вимагають від держави та інших складових політичної системи суспільства посилення владноорганізуючого впливу на систему матеріально-виробничих відносин, оскільки відповідні економічні інструменти у такі періоди виявляються нездатними забезпечити, серед іншого, стримування інфляції, своєчасну та повну виплату заробітної плати, девальвацію національної валюти тощо.

Зовсім інша справа має місце тоді, коли відповідні питання політизуються штучно або 3 суто суб’єктивних причин певного кола осіб, які полягають, як правило, у їх прагненні задовольнити свої особисті бажання та інтереси, використовуючи певні адміністративно-політичні засоби впливу на ті чи інші соціально значущі проблеми. При цьому політизація, зокрема, права є найзручнішим 
Сунєгін С. О. Правова система: проблеми ефективності в контексті сучасних тенденцій...

та найдієвішим інструментом задоволення особистих інтересів, оскільки політика пов'язана насамперед з функціонуванням держави та їі інститутів, а отже, з ексклюзивною можливістю владно впливати на будь-яку сферу суспільного життя за допомогою правових та організаційних засобів. Особливої ефективності така суб'єктивна, штучна політизація набуває в умовах сучасного стрімкого інформаційно-технологічного прогресу, який надає змогу суттєво посилювати маніпулятивний вплив політичних та бізнесових груп або суб'єктів на свідомість і волю громадян, спрямовуючи їх розвиток у вигідному лише для них напрямі.

Як приклад штучної політизації не лише права, а й по суті всього традиційного соціонормативного континууму суспільного розвитку, можна навести численні спроби сучасних демократичних європейських держав повністю «підкорити» державно-правовому забезпеченню та захисту ті соціально важливі питання, які раніше регламентувалися здебільшого нормами моралі, релігії, звичаями тощо. У зазначеному контексті мова йде насамперед про штучну політизацію правового впливу на традиційні сімейні відносини та цінності, на впровадження за допомогою політико-правових механізмів фактично необмеженої толерантності навіть всупереч пануючій громадській думці, суспільним інтересам та моралі, що закономірно викликає різного роду соціальні негаразди та конфлікти як на макро-, так і на мікрорівнях.

Очевидно, що в цих умовах, завдяки використанню відповідних політичних інструментів впливу на суспільство, межі права як особливого соціального регулятора необгрунтовано розширюються, у зв'язку з чим може бути досягнутий лише зворотний, негативний ефект його впливу на суспільство, що виражається у стрімкому поширенні серед індивідів стану соціальної аномії. При цьому останнє випливає з того, що об’єктивність цілісного соціонормативного континууму суспільства, внутрішня логіка та закономірності його історичного функціонування та розвитку, його значущість для поведінки та діяльності кожної особистості, передбачає, по-перше, наявність особливого взаємозв'язку та взаємообумовленості між правом та іншими соціальними регуляторами, зокрема, 3 мораллю та релігією i, по-друге, неможливість досягнення корисного соціального ефекту в умовах розбалансованості та дезінтеграції соціальних регуляторів між собою, оскільки кожен з них окремо не здатен ефективно впливати всю палітру внутрішніх та зовнішніх чинників формування людської волі, свідомості, звичок, характеру, вчинків, поведінки тощо.

Так, право, на відміну від моралі та релігії, за своєю природою не може суттєво впливати на багатоманітний внутрішній світ особистості, i саме тому право регламентує лише зовнішні прояви волі та свідомості індивідів, визначаючи при цьому відповідні засоби та заходи конкретного зовнішнього реагування на ту чи іншу соціально значущу поведінку. Мораль і релігія, навпаки, «прагнуть» унормувати внутрішній стан особистості таким чином, щоб не допустити назовні їі жодні деструктивні акти чи вчинки, а якщо цього досягти не вдається, то ії подальший регулятивний потенціал згасає, оскільки здебільшого не пов'язується з певними конкретними обмеженнями волі індивідів. Саме тому слід погодитися з думкою О. Львової, що чітко визначені правові межі впливу на суспільство, якими $є$ перевірені часом та історичним досвідом моральні критерії, допомагають захищати соціальний порядок в ньому [13, с. 34], сприяють нормалізації людських взаємовідносин.

Безумовно, зазначеними вище тенденціями не вичерпується вся палітра сучасних напрямів правового розвитку, які мають неоднозначний та багато в чому суперечливий характер, що, на думку автора, пов'язано не стільки з, власне, правом або правовою матерією, скільки з суб'єктним (суб'єктивним), особистісним виміром соціальної дійсності. Адже право, так само як і будь-які інші відносини в суспільстві, є результатом або продуктом усвідомленої, вольової діяльності людини, наявності та розвитку певного кола думок, ідей, концептів, здібностей, схильностей, почуттів, переживань та інших складових свідомості індивідів, які мають суперечливу, діалектичну природу, що поляризується в межах загального морального континууму «добро - зло».

3'ясувавши основні та найбільш явно виражені тенденції сучасного правового розвитку, які з різною інтенсивністю проявляють себе фактично на всіх рівнях (глобальному, регіональному та локальному), спробуємо відповісти на питання, у чому полягають основні проблеми ефективності функціонування правових систем в контексті реалій сьогодення. Так, насамперед потрібно визначитися із загальним критерієм, який надає можливість віднести правову систему до ефективно функціонуючої. Таким критерієм виступає передусім конкретна позитивна міра впливу правової системи на зміцнення нормативних засад функціонування суспільства і держави, що виражається, зокрема, у гармонійному формуванні та розвитку суспільних відносин, у належній реалізації прав, 
свобод, обов'язків та повноважень відповідних суб' єктів та суттєвому зменшенні у зв'язку із цим правових спорів між ними, у досягненні позитивних результатів поставлених суспільством перед державою завдань, у відчутті захищеності індивідів та соціальних інститутів від деструктивного втручання у їх життя певних явищ і процесів, у зростанні матеріального добробуту та духовного благополуччя громадян тощо. Якщо все це узагальнити, то можна стверджувати, що дієвість правової системи $є$ неефективною тоді, коли їі конкретні результати не сполучені $з$ досягненням визначеного соціального блага.

Звертаючись до реалій сьогодення, не можна не помітити, що позитивна результативність правової системи є достатньо низькою. При цьому мова йде не лише про вітчизняні реалії перехідного розвитку національної правової системи України, які пов'язані з об'єктивними історичними чинниками або фактами, а й про явно виражену тенденцію зниження рівня ефективності функціонування правових систем сучасних високорозвинених західних демократичних держав, що яскраво ілюструється посиленням протестних рухів, зокрема, із застосуванням насильства, всередині відповідних країн (наприклад, протестна активність так званих «жовтих жилетів» у Франції).

Таким чином, спробуємо дослідити чинники, які впливають на ефективність правової системи, крізь призму їі структури, яку, з огляду на обмеженість статейного викладу, представимо насамперед на рівні центрального елементу правової системи, який, на думку автора, має дуальний вимір - право (нормативний елемент) та суб'єкт (соціальний елемент). При цьому слід звернути увагу на те, що такий ракурс аналітики надає змогу хоча б побіжно дослідити майже всі компоненти правової системи, які умовно можна об'єднати у статичний та динамічний блоки.

Нормативний елемент правової системи, який включає в себе сукупність правових норм, принципів та інститутів, традиційно вважають центральним елементом правової системи і зазвичай позначають як «право». 3 огляду на деякі з означених вище тенденцій сучасного правового розвитку, відбувається посилення правового унормування суспільних відносин, що виражається у перманентному зростанні принаймні кількісних показників системи законодавства, а також у підвищенні ролі та значенні правових принципів у регламентації суспільних відносин, про що свідчить як факт їх все більшого закріплення у міжнародному та національному праві демократичних держав, так і їх безпосереднє використання у правовідносинах, зокрема, у судовій практиці.

Водночас факт формального зростання нормативно-правового масиву в державі та навіть безпосереднього застосування правових принципів у відповідних правовідносинах ще не означає автоматичного зміцнення соціального та індивідуального благополуччя. Останнє пов'язано з тим, що:

1) зміст правових норм і принципів не обмежується лише, власне, юридичним контекстом, а об'єктивно співвідноситься з іншими соціальними регуляторами, зокрема, з традиційною для певного суспільства мораллю, релігією, звичаями тощо. Адже очевидно, що, наприклад, такі соціальні інститути, як шлюб та сім'я, освіта і наука, соціальне забезпечення, матеріальне виробництво тощо, мають метанормативний, метаціннісний смисловий контекст, який не можна штучно «прив'язувати» лише до правової сфери, нехтуючи при цьому іншими ціннісно-нормативними рівнями їх соціальної природи. Взагалі, все те, що так чи інакше, реально або потенційно пов'язано з людською особистістю, неможливо обмежити точними та однозначними формулами, даними, прогнозами, категоріями тощо, оскільки це означатиме позбавлення людини здатності здійснювати осмислену творчо-перетворювальну діяльність.

3 цього випливає, що відповідні правові приписи, незалежно від того, що саме вони встановлюють або закріплюють (наприклад, дефініції, права і обов'язки учасників правовідносин, спеціальний правовий режим тощо), повинні узгоджуватися не лише з певним колом, зокрема, загальноприйнятих моральних імперативів або догм, а й з особливостями їх сприйняття та усвідомлення в межах визначеного соціокультурного простору, на який не в останню чергу впливає відповідна релігійна традиція. При цьому прагнення змінити або модернізувати конкретну морально-релігійну систему координат під визначений стандарт за допомогою використання правових засобів навряд чи призведе до позитивних результатів, що пов'язано як з об'єктивною неможливістю розбудови гомогенної ціннісно-нормативної системи координат в планетарному масштабі та апріорною аморальністю подібних спроб, так і з тим фактом, що сприйняття та усвідомлення відповідних правил і норм органічно містить в собі елемент «внутрішнього», «особистісного», «абсолютного» або такого, що не залежить від будь-яких зовнішніх чинників;

2) правові норми, принципи та інститути права - це засоби об'єктивації та зовнішнього вираження основних ідей соціального розвитку, у тому числі його світоглядних засад, а не лише права, 
Сунсзін С. О. Правова система: проблеми ефективності в контексті сучасних тенденцій...

навіть у його широкому або інтегративному розумінні. Утворюючи нормативну складову правової системи, вони виражають та формулюють соціально значущі поняття і конструкції, способи та форми їх осмислення і практичної реалізації, які формувалися і розвивалися протягом тривалого історичного періоду, закріплюючи у свідомості суб'єктів суспільних відносин як відповідні соціальні закономірності та засади їх сталого прогресивного розвитку, так і систему протидіючих йому чинників, здатних деструктивно впливати на суспільне життя.

У науковій літературі справедливо відзначається, що «нормативність не $\epsilon$ виключно правовим явищем як за своїм походженням, так і за роллю у суспільному житті. Нормативність $є$ первинною, вихідною властивістю соціальної матерії, зумовлюваною ії внутрішньою потребою в упорядкованості й здатності до самоорганізації. Нормативність характеризує як окремі соціальні зв'язки, так і весь суспільний розвиток. Іманентна суспільству потреба в упорядкованості знаходить прояв в нормативності суспільного розвитку. Нормативність як невід'ємна характеристика соціальної матерії може мати різні форми об'єктивації, однією з яких є, зокрема, правова норма» [14, с. 34].

Незважаючи на те, що формування змісту вказаних соціально значущих понять і конструкцій в межах визначених темпорально-просторових соціокультурних параметрів завжди $є$ результатом суб'єктивного сприйняття та усвідомлення відповідних чинників суспільного життя, в жодному разі не можна нівелювати значення їх об'єктивності, яка проявляється насамперед в їх надзвичайній важливості, значущості для належної організації суспільного життя, що неодноразово підтверджувалося історичним досвідом соціальної практики.

Так, права і свободи людини є цілісним системним явищем, яке, окрім, власне, правового контексту та обгрунтування, об'єктивно має ще світоглядні, морально-релігійні витоки та відповідний їм зміст. Водночас в умовах сучасного демократичного розвитку їх зміст штучно звужується лише до правового виміру, що проявляється, серед іншого, у конституційному закріпленні їх апріорної фундаментальності, пріоритетності та найвищої імперативності в системі соціальних цінностей.

Таке штучне звуження їх цілісного ціннісно-нормативного значення не має в своїй основі жодних об'єктивних підстав, які випливають з багатоманітності соціальної дійсності і свідчать не лише про наявність не однієї, а щонайменше декількох найвищих соціальних цінностей (наприклад, любов та сім'я, народження і виховання дітей, зв'язок та наступність поколінь; гармонійне поєднання традиційності з інноваційністю у суспільному житті; колективність та взаємодопомога, права і свободи, честь та гідність людини; совість, соціальна відповідальність та моральність людини тощо), а й про їх онтологічну необхідність, величезну значущість для забезпечення як загальносоціального, так і індивідуального блага, а також корисність для забезпечення нормального функціонування суспільства і держави на засадах законності та правопорядку. У зв'язку з цим суб'єктивне обмеження цілісного ціннісно-нормативного значення прав і свобод людини лише правовим контекстом шляхом його об'єктивації, зокрема, у загальнообов'язкових правових нормах, призведе, скоріше, до соціально шкідливого чи навіть небезпечного ефекту, ніж до корисного та суспільно необхідного. При цьому останнє особливо стосується тих суспільств, в менталітеті яких глибоко вкорінена відповідна морально-релігійна традиція, що на свідомому та навіть підсвідомому рівнях міцно унормовує поведінку та діяльність індивідів.

Отже, правопорядок як реальний якісний показник ефективності правового регулювання суспільних відносин означає значно більше, ніж юридичний вимір суспільних відносин, оскільки право, виражене у формі законодавства, функціонує не у вакуумі, а у безпосередньому взаємозв'язку з іншими складовими соціальної нормативності. При цьому від характеру таких взаємозв'язків всередині континууму соціальної нормативності безпосередньо залежить якість життя індивідів та суспільства, оскільки соціальна система у загальному значенні конструює неоднорідну систему цінностей, зміст та структура яких свідчать про неможливість та недоцільність як їх штучного поглинання одна одною, так і протиставлення між собою. Окремі ж суб'єктивні прагнення до руйнування єдності та цілісності континууму соціальної нормативності може призводити лише до дискредитації та деформації змісту відповідних норм, внаслідок чого деструкції зазнає сама свідомість особистості, зокрема правова.

Необхідно зазначити, що характеристика права як центрального елементу правової системи не може мати завершеного цілісного характеру, якщо за дужки виноситься його органічний взаємозв'язок з особистістю, яка конституює його смислові акценти. Саме нерозривність взаємозв'язку та взаємообумовленості права і особистості, що випливає з факту неможливості існування права 
за межами людської свідомості, у тому числі у позитивній (матеріальній) формі, є свідченням того, що центральний елемент правової системи має дуальну природу.

У зв’язку з цим, слід погодитися 3 думкою, що нормативність права є похідною від нормативності людської свідомості, що нормативність - це не лише зовнішне по відношенню до особистості явище, на чому зазвичай акцентують увагу науковці, а іманентна властивість їі свідомості. Як справедливо зазначають деякі дослідники, «нормативність має всеохоплюючий характер і являє собою універсальний засіб упорядкування і розвитку як думок, так і поведінки індивідів; бере свій початок в природі людини і обумовлена особливостями ii психіки, іiі соціальної орієнтації, а також фізіологічними механізмами ії життєдіяльності» [15, с. 59].

Значущість дослідження суб'єкта або особистості як одного із аспектів або ракурсів визначення центрального елементу правової системи обумовлюється, зокрема, тим, що реалізація будь-яких суспільних відносин, у тому числі владного впливу публічних органів на суспільство і громадян, завжди замикається на конкретній людині, а не на визначеній організаційній структурі. У контексті визначення відповідних структурних рівнів правової системи це означає, що:

1) по-перше, будь-яке правовідношення - це значно більше, ніж та абстрактна або чітко визначена модель, що закладена у змісті правової норми. Адже в реальних правовідносинах, поряд iз визначеним у законі правовим режимом їх здійснення, завжди знаходять свій прояв чимало інших об'єктивних (наприклад, фактично домінуюча в суспільстві ідеологічна система, місце звичаїв, моралі та релігії у соціальному житті тощо) та суб'єктивних чинників (наприклад, світоглядні, психологічні параметри учасників правовідносин, рівень їх моральної свідомості, особливості їх особистого характеру, звичок, уподобань, переконань тощо);

2) по-друге, справжня соціально корисна якість правовідношення, його позитивна результативність, пов'язана не стільки $з$ формальною досконалістю правових приписів, скільки з узгодженістю їх смислового контексту 3 домінуючою у суспільстві ціннісно-нормативною системою координат його функціонування та розвитку, яка належним чином сприймається громадянами як така, що веде суспільство до прогресу, а не регресу. Якщо ж відповідна ціннісно-нормативна система координат в реальному суспільному житті не сприймається як прогресивна шкала, то правове регулювання суспільних відносин в жодному разі не досягне закладеної в ньому мети - упорядкування суспільних відносин, їх закріплення, охорона, захист та стимулювання прогресивного розвитку в майбутньому. Навпаки, в цих умовах закріплення ідейних засад такої ціннісно-нормативної системи координат на правовому, зокрема, конституційному рівні, та навіть їх поширення у суспільстві за допомогою інших механізмів, може призвести до посилення такого негативного внутрішнього явища у свідомості індивіда, як когнітивний дисонанс, тобто стану його психічного дискомфорту, що обумовлений неузгодженістю або зіткненням у його свідомості суперечливих, взаємовиключних уявлень (вірувань, емоцій, цінностей тощо).

Таким чином, ефективність реалізації правовідносин в суспільстві залежить насамперед від того, наскільки правильно враховані всі об'єктивні соціокультурні засади розвитку такої складноорганізованої системи, як суспільство. Зрозуміло, що соціокультурний вимір життя суспільства завжди поєднує в собі насамперед історично обумовлену специфіку взаємодії та взаємозв' язку трьох найбільших соціальних регуляторів (права, моралі та релігії), взаємообумовленість яких протягом тривалого історичного періоду не лише закладала міцний світоглядний фундамент у громадську свідомість, а й до певної міри сформувала глибинні рівні індивідуальної та колективної підсвідомості. У зв'язку з цим потрібно підтримати думку деяких сучасних науковців, згідно із якою «стає все більш очевидним, що складноорганізованим системам не можна нав'язувати шляхи їх розвитку. Значно доцільніше зрозуміти, яким чином можна сприяти розвитку їх внутрішніх тенденцій, тобто яким чином можна простимулювати їх самоорганізацію. Іншими словами, проблема керованого розвитку містить в собі і проблему самокерованого розвитку» [16, с. 215];

3) по-третє, якщо звернутися до такого різновиду юридичної діяльності, як правозастосування, то його належна реалізація також об'єктивно виходить за межі формальних правових приписів, у тому числі в тих випадках, коли відповідні правовідносини або індивідуальні справи детально регламентуються нормами права. Адже фактичні суспільні відносини, які регламентуються правом, завжди можна також охарактеризувати у контексті їх ціннісно-смислового значення, явних, а в багатьох випадках і завуальованих намірів їх учасників, їх конкретних дій або вчинків в межах цих відносин, особливостей дотримання правил етики їх здійснення тощо. При цьому ці, а та- 
Сунєгін С. О. Правова система: проблеми ефективності в контексті сучасних тенденцій...

кож чимало інших чинників, які не мають правового виміру, справляють визначений вплив на свідомість відповідного суб'єкта правозастосування, наділеного повноваженнями щодо вирішення відповідної справи та прийняття індивідуального правового акта по ній. У зв'язку з цим виникає необхідність в упорядкуванні зазначених чинників таким чином, щоб в результаті вирішення певної індивідуальної справи зміцнювався, а не порушувався режим законності і правопорядку в суспільному житті. Досягти ж цього можна лише у тому випадку, якщо система або ієрархія соціальних цінностей правильно усвідомлюється суб'єктом правозастосування, зокрема, у контексті морального обгрунтування, не обмеженого дескприптивним контекстом;

4) по-четверте, безпосередні суб'єкти державно-владної діяльності (державні службовці з загальним та спеціальним статусом, вищі посадові особи держави тощо) приймають рішення, виконують певні дії чи, навпаки, відмовляються від їх виконання, виходячи не лише 3 рівня свого особистого професіоналізму, компетентності та загального інтелектуального потенціалу, а й 3 внутрішніх психічних процесів і станів (відчуття, сприйняття, емоції, пам'ять, наміри, схильності, переконання тощо), які формуються та розвиваються під впливом значної кількості суб' єктивних та об'єктивних чинників, що не обмежуються лише соціальним виміром. Саме тому якість державно-владної діяльності, а отже, позитивний вплив на конкретні долі необмеженого кола осіб, не вимірюється одними лише формальними параметрами на кшталт професіоналізму, освіти чи досвіду роботи, а пов'язується насамперед зі здатністю відповідних суб'єктів спрямовувати свої свідомо-вольові якості на досягнення моральних чеснот та ідеалів.

Таким чином, ефективність функціонування організаційного елементу правової системи безпосередньо залежить не лише від рівня якості відповідної нормативно-правової бази та формального факту здобуття відповідної освіти, на що зазвичай звертається увага у науковій літературі [17, с. 89-95], а й від моральної вихованості кадрового потенціалу державної служби, формування якої починається 3 традиційної сім’ї і продовжує розвиватися в процесі соціалізації в інших соціальних інститутах (освіта, економіка, політика, мораль, релігія, мова, ЗМІ, правова система, різні соціальні групи тощо) або у прогресивному, або у регресивному напрямі, залежно від особливостей ціннісно-нормативних домінант, пануючих в них та у суспільстві.

3 огляду на зазначені вище тенденції сучасного правового розвитку, неважко переконатися у тому, що жодні формально здійснювані реформи у відповідних сферах та галузях суспільного життя ніколи не призведуть до соціально корисного ефекту навіть у короткостроковій перспективі, якщо в суспільстві нівелюється значення моралі взагалі, тобто як особливого соціального регулятора, а також моральних якостей осіб, уповноважених на виконання функцій та завдань держави. При цьому потрібно чітко усвідомлювати, що законність і правопорядок в суспільстві пояснюються та обгрунтовуються двома взаємообумовленими, взаємодіючими процесами: 3 одного боку, все більшим зростанням моральної свідомості населення відповідної держави, а 3 іншого - особистими моральними якостями державних управлінців.

Висновки. Таким чином, можемо зробити наступні висновки:

1. Сучасні тенденції правового розвитку свідчать про спроби суб'єктивного втручання у внутрішню логіку та закономірності функціонування всієї системи соціальних регуляторів. Узагальнюючи їх зміст, можна констатувати наявність своєрідного парадоксу, а саме: 3 одного боку, суспільні відносини все більше формально унормовуються за допомогою права на всіх його рівнях, а з іншого - право як особлива соціонормативна система все більше втрачає свій авторитет у суспільному житті, який, як свідчить практика, не покращується шляхом прийняття все «кращих» i «кращих» законів. Вказаний парадокс ускладнюється ще й тим фактом, що мова йде не про авторитарні та тоталітарні, а демократичні політичні режими, в межах дії яких все більше загострюються як зовнішні соціальні протиріччя та конфлікти, так і внутрішні стани свідомості індивідів, які все складніше піддаються належному (позитивному) соціонормативному впливу.

2. Право, як і будь-яка інша об'єктивно функціонуюча в суспільстві соціонормативна система, відтворює у своєму змісті визначену ціннісну матрицю позитивної організації суспільного життя, що має ієрархічну будову. Конкретний зміст цієї матриці на внутрішньодержавному рівні визначається насамперед на рівні конституції як найвищого за юридичною силою та найавторитетнішого акта у будь-якій державі, а деталізується у нормах галузевого законодавства, якими оформлюється визначений правовий режим здійснення прав і обов’язків учасників відповідних відносин. Поряд із внутрішньодержавним рівнем ретрансляції вказаної ціннісної матриці, ії зміст представ- 
лений також на рівні міжнародного права, а також, що не менш важливо, відтворюється в інших механізмах впливу на волю і свідомість, а отже, на поведінку та діяльність індивідів (наприклад, через 3MI, мистецтво тощо). При цьому основна проблема полягає у тому, що ціннісна шкала суспільного та індивідуального розвитку, представлена у сучасному демократичному праві та відтворена у діяльності багатьох інших соціальних інститутів, не лише не враховує об'єктивно функціонуючу складноорганізованість людського життя, а й передбачає надто спрощений, примітивний та по суті помилковий шлях досягнення так званого «суспільства добробуту».

3. Ефективність правової системи, тобто її реальна здатність забезпечувати законність і правопорядок у суспільному та державному житті, залежить не лише від ступеня формального закріплення та відображення у змісті правових норм загальних метанормативних засад організації людського співжиття (наприклад, свобода, рівність, справедливість тощо), а й безпосереднього сприйняття та усвідомлення їх змісту з боку індивідів як такого, що відповідає єдності їх цілісної соціокультурної традиції та найбільш повно і точно узгоджується зі складністю та багатоаспектністю соціального буття. Правова система, з огляду на соціальний вимір ії регулятивно-охоронного впливу, об'єктивно не здатна самостійно або автономно від інших соціальних регуляторів забезпечити реальний правопорядок в суспільстві та його прогресивний розвиток. Адже в соціумі, в якому моральні принципи та поняття (наприклад, совість, сором, відповідальність, честь тощо) втратили своє об'єднуюче та чітко усвідомлене більшістю його представників значення, правопорядок існує лише як визначений симулякр, а не справжнє явище, оскільки його основою в цьому випадку може бути лише державно-владний примус. Очевидно, що такий «правопорядок» навряд чи матиме довгострокову темпорально-просторову перспективу свого функціонування.

\section{Список використаних джерел}

1. Лукач I. B. Значення поділу права на приватне та публічне в господарських відносинах // Електронне наукове видання «Порівняльно-аналітичне право». - 2016. - № 3. - С. 107-109. - URL: http://www.pap.in.ua/3_2016/30.pdf

2. Чепис O. I. Значення приватних та публічних інтересів для формування цивільного права // Науковий вісник Ужгородського університету. Серія «Право». - 2010. - Вип. 13. - С. 261-265.

3. Погребняк С. П. Поділ права на публічне і приватне (загальнотеоретичний аспект) // Державне будівництво та місцеве самоврядування. - 2006. - Вип. 12. - С. 3-17.

4. Каманина Т. В. Корпоративное право : учеб. - 5-е изд., перераб. и доп. - М. : Издательство «Юрайт»; Высшее образование, 2010. - 899 с.

5. Андреев В. К. Об управлении государственным имуществом, о недвижимости и предприятии // Предпринимательское право. - 2004. - № 1. - С. 25-28.

6. Шкабаро В. М., Рибіна С. А. Деякі аспекти проблематики колізійності законодавства України // Вісник Дніпропетровського університету імені Альфреда Нобеля. Серія «Юридичні науки». - 2013. - № 2 (5). - С. 114-119.

7. Нерсесяни В. С. Процессы универсализации права и государства в глобализирующемся мире // Государство и право. - 2005. - № 5. - С. 38-47.

8. Марченко М. Н. Тенденции развития права в современном мире: учебное пособие. - М. : Проспект, $2015 .-376$ с.

9. Таранюк А. О. Проблемні аспекти уніфікації законодавства України на шляху до єдиного правового простору // Науковий вісник Ужгородського національного університету. Серія «Право». - 2016. - Вип. 40. - Т. 1. - С. 15-19.

10. Оніщенко Н. М. Співвідношення внутрішньодержавного і міжнародного права: наукові реалії сьогодення // Вісник Національної академії правових наук України. - 2015. - № 1 (80). - С. 29-36.

11. Поздняков Э. А. Философия государства и права. - [2-е изд., исправ. и доп]. - М. : Изд-во «Весь мир», 2016. $344 \mathrm{c.}$

12. Оніщенко Н. М. Правова аналітика: доктринальний підхід та практичне осмислення // Альманах права. Правова аналітика: доктринальні підходи та галузеві виміри. - Вип. 9. - К. : Ін-т держави і права ім. В. М. Корецького НАН України, 2018. - С. 35-39.

13. Львова О. Л. Межі толерантності українських законів: аналітико-правовий зріз // Держава і право: Збірник наукових праць. Серія «Юридичні науки». Вип. 82 / Ін-т держави і права ім. В. М. Корецького НАН України. К. : Вид-во «Юридична думка», 2018. - С. 23-36.

14. Заморська Л. І. Нормативність права як соціальна цінність // Актуальні проблеми політики: зб. наук. пр. / редкол.: С. В. Ківалов, Л. І. Кормич, Ю. П. Аленін. - Одеса : Фенікс, 2012. - Вип. 45. - С. 28-37.

15. Вележев C. C. Нормативность права как проявление нормативности сознания // Вестник Владимирского юридического института. - 2011. - № 2 (19). - С. 58-60.

16. Малько А. В. Стимулы и ограничения в праве. - 2-е изд., перераб. и доп. - М. : Юристъ, 2004. -250 с.

17. Тимофієв B. Актуальні питання удосконалення кадрового потенціалу державної служби // Вісник Національної академії державного управління при Президентові України. - 2012. - Вип. 4. - С. 89-95. 


\section{References}

1. Lukach I. $V$. Znachennia podilu prava na pryvatne ta publichne v hospodarskykh vidnosynakh // Elektronne naukove vydannia «Porivnialno-analitychne pravo». - 2016. - № 3. - S. 107-109. - URL: http://www.pap.in.ua/3_2016/30.pdf

2. Chepys O. I. Znachennia pryvatnykh ta publichnykh interesiv dlia formuvannia tsyvilnoho prava // Naukovyi visnyk Uzhhorodskoho universytetu. Seriia «Pravo». - 2010. - Vyp. 13. - S. 261-265.

3. Pohrebniak S. P. Podil prava na publichne i pryvatne (zahalnoteoretychnyi aspekt) // Derzhavne budivnytstvo ta mistseve samovriaduvannia. - 2006. - Vyp. 12. - S. 3-17.

4. Kashanina T. V. Korporativnoe pravo: uchebnik. - 5-e izd., pererab. i dop. - M. : Izdatel'stvo «Yurajt»; Vysshee obrazovanie. $-2010 .-899$ s.

5. Andreev V. K. Ob upravlenii gosudarstvennym imushchestvom, o nedvizhimosti i predpriyatii // Predprinimatel'skoe pravo. - 2004. - № 1. - S. 25-28.

6. Shkabaro V. M., Rybina S. A. Deiaki aspekty problematyky koliziinosti zakonodavstva Ukrainy // Visnyk Dnipropetrovskoho universytetu imeni Alfreda Nobelia. Seriia «Iurydychni nauky». - 2013. - № 2 (5). - S. 114-119.

7. Nersesyanc V.S. Processy universalizacii prava i gosudarstva v globaliziruyushchemsya mire // Gosudarstvo i pravo. 2005. - № 5. - S. 38-47.

8. Marchenko M. N. Tendencii razvitiya prava v sovremennom mire: uchebnoe posobie. - M. : Prospekt, 2015. - $376 \mathrm{~s}$.

9. Taraniuk A. O. Problemni aspekty unifikatsii zakonodavstva Ukrainy na shliakhu do yedynoho pravovoho prostoru // Naukovyi visnyk Uzhhorodskoho natsionalnoho universytetu. Seriia «Pravo». - 2016. - Vyp. 40. - T. 1. - S. 15-19.

10. Onishchenko N. M. Spivvidnoshennia vnutrishnoderzhavnoho i mizhnarodnoho prava: naukovi realii sohodennia // Visnyk Natsionalnoi akademii pravovykh nauk Ukrainy. - 2015. - № 1 (80). - S. 29-36.

11. Pozdnyakov E. A. Filosofiya gosudarstva i prava. - [2-e izd., isprav. i dop]. - M. : Izd-vo «Ves' mir», 2016. - 344 s.

12. Onishchenko N. M. Pravova analityka: doktrynalnyi pidkhid ta praktychne osmyslennia // Almanakh prava. Pravova analityka: doktrynalni pidkhody ta haluzevi vymiry. - V. 9. - K. : In-t derzhavy i prava im. V. M. Koretskoho NAN Ukrainy, 2018. - S. 35-39.

13. Lvova O. L. Mezhi tolerantnosti ukrainskykh zakoniv: analityko-pravovyi zriz// Derzhava i pravo: Zbirnyk naukovykh prats. Seriia «Iurydychni nauky». Vypusk 82 / In-t derzhavy i prava im. V. M. Koretskoho NAN Ukrainy. - K. : Vydvo «Iurydychna dumka», 2018. - S. 23-36.

14. Zamorska L. I. Normatyvnist prava yak sotsialna tsinnist // Aktualni problemy polityky: zb. nauk. pr. / redkol.: S. V. Kivalov, L. I. Kormych, Yu. P. Alenin. - Odesa : Feniks, 2012. - Vyp. 45. - S. 28-37.

15. Velezhev $S$. S. Normativnost' prava kak proyavlenie normativnosti soznaniya // Vestnik Vladimirskogo yuridicheskogo instituta. - 2011. - № 2 (19). - S. 58-60.

16. Mal'ko A. V. Stimuly i ogranicheniya v prave. - 2-e izd., pererab. i dop. - M. : Yurist», 2004. - $250 \mathrm{~s}$.

17. Tymofiiev $V$. Aktualni pytannia udoskonalennia kadrovoho potentsialu derzhavnoi sluzhby // Visnyk Natsionalnoi akademii derzhavnoho upravlinnia pry Prezydentovi Ukrainy. - 2012. - Vyp. 4. - S. 89-95.

\section{Сунєгін С. О. Правова система: проблеми ефективності в контексті сучасних тенденцій правового розвитку}

Стаття присвячена дослідженню проблем ефективності правової системи в контексті основних тенденцій сучасного правового розвитку. Наголошується, що сучасні тенденції правового розвитку свідчать про спроби суб'єктивного втручання у внутрішню логіку та закономірності функціонування всієї системи соціальних регуляторів. Обгрунтовується думка, що ефективність правової системи залежить насамперед від єдності та цілісності континууму соціальної нормативності, який має об'єктивно-суб'єктивний вимір.

Ключові слова: правова система, мораль, соціальна нормативність, особистість, свідомість, правопорядок, законодавство.

\section{Sunegin S. O.The legal system: problems of efficiency in the context of modern trends of legal development}

The article is devoted to the study of the problems of the efficiency of the legal system in the context of the main trends of modern legal development. In particular, as the main trends of modern legal development, it is proposed to distinguish the following: 1) strengthening of legal regulation of both private and public relations, which is expressed, in particular, in the growth of the legal and regulatory array or the number of legal acts of various legal force governing the relevant social relations; 2) universalization and unification of law, which increasingly acquire a multidimensional, internally contradictory nature, and are most pronounced in the economic sphere of public life; 3) strengthening and, at the same time, complicating the interconnection and interaction of international, regional and national law; 4) the tendency of politicization of law both at the international and national levels.

The indicated tendencies of legal development testify to attempts of subjective interference in internal logic and regularities of functioning of the whole system of social regulators. Summarizing their content, we can state the presence of a peculiar paradox, namely: on the one hand, social relations are increasingly formalized with the help of law at 
all its levels, and on the other - law as a special socio-regulatory system is increasingly losing its credibility in public life, which, as practice shows, is not improved by the adoption of all the «best» and «best» laws. This paradox is complicated by the fact that it is not authoritarian and totalitarian, but democratic political regimes, within the scope of which are increasingly exacerbated by external social contradictions and conflicts, and internal states of consciousness of individuals, which are increasingly difficult to cope with the proper (positive) socio-regulatory impact in general.

Law, like any other socio-normative system objectively functioning in society, reproduces in its content a definite value matrix of a positive organization of social life that has a hierarchical structure. The specific content of this matrix at the national level is determined primarily at the level of the constitution as the highest legal force and the most authoritative act in any state, and is detailed in the norms of sectoral legislation, which formalize a certain legal regime of the exercise of rights and obligations of participants in the relevant relations. The main problem is that the value scale of social and individual development, presented in modern democratic law and reproduced in the work of many other social institutions, not only does not take into account the objectively functioning complex organization of human life, but also involves a very simplistic, primitive and essentially false way of achieving the so-called «welfare society».

The effectiveness of the legal system, that is, its real ability to ensure the law and order in society and public life, depends not only on the degree of formal consolidation and reflection in the content of the legal norms of the general metanormative principles of organization of human co-existence (for example, freedom, equality, justice, etc.), but also the direct perception and awareness of their content on the part of individuals as such, which corresponds to the unity of their integral socio-cultural tradition and most fully and precisely consistent with the complexity and multi-dimensionality of social life in general. The legal system, taking into account the social dimension of its regulatory and protective influence, is objectively unable to independently or autonomously of other social regulators to provide a real legal order in society and its progressive development. Indeed, in a society in which the moral principles and concepts (for example, conscience, shame, responsibility, honor, etc.) have lost their unity and clearly understood by the majority of its representatives meaning, the rule of law exists only as a certain simulacrum, and not a real phenomenon, because its basis in this case can be only state-power coercion.

Key words: legal system, morality, social normativism, personality, consciousness, law and order, legislation.

DOI: 10.33.66.3/2524-017X-2019-10-252-264 